\title{
El envío en El castillo de la carta cifrada de Javier Tomeo'
}

\author{
Sergio Vergara Alarcón
}

Universidad de La Serena

La sola historia que uno se cuenta siempre, que uno se dirige a sí mismo, la poética de lo propio como reconciliación, como consuelo, serenidad.

JACQUes DerRida

\begin{abstract}
La situación narrativa que abre la novela en la secuencia de acciones es, al parecer, simple: Bautista, el siervo del Marqués, debe llevar una carta al Conde de X, don Demetrio del Costillar. La performance consiste en la apertura de un circuito comunicativo que no se concreta y que sólo se verbaliza, o que debería concretarse en la prospectiva. El recorrido abierto a través de este intermediario es el envío mismo y su teatralización y ello se privilegia indicialmente, ya que se sostiene que la carta significa "la vuelta al mundo de los vivos", una "resurrección" para el emisor, el Marqués. Detengámonos un momento en la estructura comunicativa de la narración ${ }^{2}$.

El narrador (el Marqués) abre la comunicación en el plano 3 y se dirige a un narratario, Bautista. Sin embargo, la primera enunciación se da en segunda persona (de cortesía) y en presente. "No se preocupe, Bautista, y deje de temblar" con todo, es el narratario quien habla, a través del deíctico temporal y el modo verbal en pretérito indefinido y cita al narrador en discurso directo. "-me dijo aquella mañana el señor Marqués”. En consecuencia, todo el soliloquio
\end{abstract}

${ }^{1}$ Manejamos la edición de Anagrama, Barcelona, Tomeo, Javier, El castillo de la carta cifrada, 1998.

${ }^{2}$ Para este análisis y sus bases epistemológicas, ver: Meyer-Minnemann, Klaus. "Narración homodiegética y segunda persona en Cambio de piel, de Carlos Fuentes", en: Acta literaria, Concepción (Chile), № 9, 1984. 
del narrador es una cita -en presente- de lo que recuerda el narratario, quien reconstruye el mensaje, que es la diégesis (contenido narrativo) eventual de lo que "debería haber pasado". El presente de la enunciación es focalizado a través del raconto del narratario apelado como "usted" que abre el relato. Lo interesante aquí es el hecho de que este discurso directo es la narración de lo que aún no ha sucedido (desde el presente de la enunciación) ${ }^{3}$.

En El castillo de la carta cifrada no hay intercambio de rol entre narrador y narratario (Bautista no dice nada, su única frase es la citada arriba, sólo manifiesta gestualmente lo que piensa).

El autor implícito pone al narrador enfatizando claramente una posición del narrador sin destinatario del envío, y silencia la voz del narratario. Es, en suma, un soliloquio que signaliza la no comunicación, comunicando la necesidad de comunicación.

Soy hombre que, a pesar de todo, siente la imperiosa necesidad de comunicarse con los demás. He permanecido demasiado tiempo en silencio, y con esta nueva primavera renació en mí la necesidad de escribir cartas y de encontrar destinatarios idóneos (p. 30).

En la eventualidad de la entrega de la carta a su destinatario, el narrador, el Marqués, cita posibles diálogos entre su narratario-portador y su destinatario, en el plano de comunicación de los personajes. De esta manera, el narratario (Bautista) cita en discurso directo los diálogos entre él y el destinatario de la carta (agentes ahora en el plano 4), tal como se los aprendió según recomendación u orden del Marqués. Por lo tanto, en esos diálogos, el narrador es agente de una historia contada por el narratario e inventada por aquél (en el plano 3):

Refiérase, por ejemplo, a la fecundidad de la vida contemplativa. $\mathrm{O}$ al horror que me inspira mi siglo. "Verá usted, Don Demetrio" - puede explicarle(...) Podríamos darle un centenar de motivos, eso es cierto, pero prefiero recurrir al lance de las sanguijuelas. Una historia cargada de simbolismo. "Hace veinte años -le explica-, mi Señor, estuvo en la ciudad. Por la mañana, al salir del hotel..." (pp. 50-51).

En cualquier caso, estas referencias son sólo susceptibles de ser citadas en el aquí y ahora de la narración por Bautista. En consecuencia, el narrador (Marqués) deviene "él" en el enunciado que debe aprender el narratario cuando se

${ }^{3}$ Las posibilidades del recurso son aquí variadas y complejas. No insistiremos en un análisis exclusivamente narratológico, sólo sirve al interés de determinar el sentido del uso de las técnicas actualizadas. 
comunique con don Demetrio, sujeto del enunciado de la narración enmarcante.

Por lo tanto, el narratario Bautista es sólo homodiegético en la eventualidad de una historia respecto de un él (enunciado), pero no de un hecho que ha pasado "en verdad". Eso no termina de saberse.

Se podría incluso afirmar, sin riesgo de equivocarse, que en este singular caso es el discurso del narrador proyección del narratario, en la forma de una larga cita soliloquial ${ }^{4}$, que es toda la novela.

Veremos luego el sentido de esta estrategia narrativa para la postulación de algunas isotopías textuales.

Debemos conceder el hecho de que en el plano narrativo, el que "sabe" lo que pasó (dijo) se repliega para dar paso a un yo que habla, imagina, ironiza, confiesa, anuncia, prevé, todo el tiempo. El texto trabaja exclusivamente con supuestos de respuestas, de reacciones, calcula todos los movimientos posibles de la recepción. En verdad, quien se comunica es el Marqués con Bautista y el pretexto es la carta.

Sabemos claramente por los indicios, que entre los interlocutores de la carta existe una prehistoria de rivalidad y el emisor instala a Bautista como instancia mediadora, y así la carta no entra en ningún circuito. La novedosa posibilidad de la narración en segunda persona hace que el único informado sea Bautista y nosotros (lectores) como testigos del envío. El narrador (destinador) sólo entrega dosificados indicios al destinatario ( $\mathrm{y}$ al lector) de lo que realmente "se trata". El envío no tiene lugar, sino a través de una performance pre-dispuesta, en preparación. Por lo tanto, toda la novela es, en cierto sentido, un acto de performatividad. El evento realmente concreto es el futuro inmediato del acto de portar la carta.

En la topología, la carta no tiene lugar, puede ser enviada, la pragmática ya está realizada en las variedades de su montaje, la carta se constituye como "al portador", en el concurso de las circunstancias del envío. Entonces, la carta no es volante como la robada de Poe, el emisor avisora todas las determinaciones de los sujetos en este triángulo singular, donde el receptor intratextual (el narratario) es mudo, ironía onomástica para quien debería ser el que nombra. A la vez, en el mismo estrato indicial, se avisa que Bautista padece de una cojera, rasgo otra vez disonante para este "nuevo Miguel Strogoff, (...) animoso correo del Zar" (p. 83). El narratario de la historia es también un servidor en el plano comunicativo, ya que "cede" el relato (aunque reproduce literal-

${ }^{4}$ En Meyer-Minnemann se discute la posibilidad de que el narratario sea proyección del narrador. Creo ver aquí un caso contrario. Todo el texto es la cita vehiculada gracias a la memoria del narratario. 
mente el discurso del narrador) a su señor, en virtud de ello, se retira. Realiza lo que podemos llamar, con Michel Tournier una función "fórica"s.

Bautista es, en este sentido, el pretexto fático del circuito entre dos interlocutores, circuito aun no abierto y virtual, según avanzamos en la lectura de la novela.

En el plano secuencial, en realidad no hay acción alguna, sino la narración de los posibles acontecimientos, narraciones o discursos que podrían tener lugar desde el momento en que Bautista abandone el castillo de su amo tras el cumplimiento de la misión. La narración aquí es anticipatoria, prevé, supone, presupone, juzga, prejuzga, prepara todas las posibilidades de acción: ataque, defensa, simulación para lograr la entrega, disimulo, actitud estoica en caso de violencia por parte del destinatario de la carta, el Conde, etc. Para ello, se hacen presentes todos los recursos canónicos de la narración folclórica: el talismán, las pruebas, las virtudes heroicas, la recompensa, el viaje como "servicio", etc. A nivel indicial, las referencias del narrador son bufonescas, ridículas, esperpénticas, desde una mirada prestigiosa a la altura social de los interlocutores y ellas son expuestas a través de figuras como la iteración, la dilación, la ironía, la hipérbole, las imágenes alucinatorias, excéntricas; las obsesiones, especialmente notables en el ámbito de la zoología y, particularmente, de la entomología. La figura del relato es dominantemente la hipertrofia. Esto se puede extender a las figuras de la emblemática y del bestiario que ocupan un lugar privilegiado en el relato: el uso de la rana verde, por ejemplo, que en la simbología occidental representa los heraldos de la fertilidad, el grado superior de la evolución y la idea de resurrección y que alterna aparición y desaparición. En el esoterismo, como el basilisco, rompe la luz astral por absorción. Y la nota indicial del verde (color preferido del Conde) que representa un matiz de comunicación entre ambos grupos en la cromática: los cálidos y los fríos. Es color de la vida vegetal y del cadáver ${ }^{6}$ (no es casual, en consecuencia, el nombre del detinatario, Demetrio, del griego Demeter, que significa "el que ama la tierra", la verdura).

Envío oblicuo, con parapetos y bifurcaciones, en clave: carta cifrada que resiste a la vigilancia de la exterioridad, a las formas de la amenaza:

“'me pregunta quiénes son esos enemigos? No sea ingenuo, hombre de Dios. Son los de siempre. Son todas esas moscas que, desde hace años, viven sobre el cadáver de nuestra infelicidad, sobre la tristeza de nuestras soledades. Son los

${ }^{5}$ Vid. Tournier, Michel. El viento paráclito. Madrid, Santillana Alfaguara literaturas, 1994, pp. 123 ss.

${ }^{6}$ Cfr. Juan Eduardo Cirlot. Diccionario de simbolos. Barcelona: Ediciones Siruela, 1997. 
que, como decía el poeta, se complacen filtrando veneno en la sangre de los hombres (...). Forman a nuestro alrededor, una vasta organización. Sitian día y noche nuestros castillos y no permiten que de ellos entre o salga el más leve mensaje de amor" (p. 99).

De allí que se justifique el hermetismo del texto.

"Mi carta es una obra maestra de la oscuridad", o "puede significar el comienzo de una nueva Edad de Oro", o: "significa ni más ni menos mi resurrección al mundo de los vivos" (p. 66) (frase situada en el lugar estratégico que es el centro del texto). En consecuencia, la carta concreta el juego lisibilidad/ ilisibilidad en tanto se explicita como un test, como un experimento y evidencia el carácter altamente apelativo que el texto reviste. El mismo texto es una gran oración, sin fragmentos, sin párrafos, sin "lugares indeterminados"7. La escritura, la historia fluye en tanto relación analógica entre letras e insectos, letra microscópica que el destinatario apenas logrará leer en sentido físico del término: "Mi letra es tan pequeña que nadie, ni siquiera con la ayuda de una potente lupa, podría leerla. Una auténtica miniatura, una microscopiez” (p. 28).

El narrador entrega garabateada una historia como legado y ofreciéndose al prestigio de la escritura, del nombre propio (único sintagma legible de la misiva), aunque, una escritura histriónica, bufonesca, el narrador insiste en el carácter ininteligible y en clave de su escrito, ya que narra "historias simbólicas". Todo ello dificulta la recepción, la demora, escamotea, retarda, difiere; todo lo cual contribuye a la eficaz tensión en la apertura de expectativas del lector. El texto es finalmente una gran divagación: "tengo una excesiva propensión a las divagaciones", "Dios me perdone, por haber dado tantos rodeos para decir una cosa tan simple"(p. 49).

Todo el relato, en los diversos estratos que lo constituyen, no es sino la búsqueda de destinatario. El marqués busca al Conde, don Demetrio, Bautista debe buscar a su destinatario que debe recibir, de sus manos, la carta. El lector implícito busca actualizar los potenciales de sentido del relato y apropiarse o no de la axiología textual; debe suponer la entrega de la misiva, pues si tuvo lugar o no, ello debió haber acontecido desde el presente del recuerdo de Bautista.

La novela tematiza la cuestión de la ausencia de interlocución, carta en clave, ininteligible, escrita en jeroglíficos, narratario silencioso, don Demetrio que dice, dialoga, según lo que el destinador supone va a decir, etc. La novela es una crítica al "acontecimiento", es la clausura de los hechos: la develación,

${ }^{7}$ Vid. Wolfgang Iser. "Die appellstruktur der Texte. Unbestimmheit als Wirkungsbedingung literarischer Prosa”, en: Warning, Rainer. Rezeptionsästhetik, München, Wilhelm Fink Verlag, 1975, pp. 228-252. 
no en clave, esta vez, del autismo, la soledad: "Esa, y no otra, es la razón de esta carta, Bautista amigo. Saber que, de algún modo, esta misma tarde alguien pensará en mí". Sin embargo: "Hagámonos con la secreta esperanza de que no entienda ni una sola palabra de las que escribo. Me concedo a mí mismo el beneficio de la oscuridad". La reclusión como forma de desconexión, la locura como forma de renuncia. Y quizá un llamado para que todos los agentes, personajes de los diversos niveles comunicativos, puedan articular una voz desde sí mismos.

El presente de la enunciación activado cada vez en la lectura es la materialización (su intento) del otro en estado de escucha, para que el yo enunciante sea, en una de sus formas más gozosas: "Porque mi carta, Bautista -no recuerdo ahora si ya se lo dije, pero, si no lo dije, lo digo ahora- es, sobre todo, un intento de diálogo, y un intento de diálogo es siempre una posibilidad de amor" (p. 90). 